\title{
The Countermeasure Study of Theme Hotel in the View of Silk Road Economic Belt - Case study of Development of Theme Hotel in the Region of Xinjiang
}

\author{
Ji Ma \\ College of Tourism, Xinjiang University, Urumqi, 830049, China
}

\begin{abstract}
Keywords: Silk Road Economic Belt; Theme Hotel; Countermeasure Study
\end{abstract}
\begin{abstract}
The concept of "Silk Road economic belt"will promote the energy cooperation, trade cooperation,financial cooperation, and certainly will facilitate the development of tourism. To develop tourism will contribute in adjusting the industrial structure and providing employment projects.Developing theme hotel will offer the new competitiveness and economic growth for the countries and regions under the Silk Road economic belt. This Article provides the developing countermeasure of theme hotel from the perspective of theme innovation, business model innovations, products and service innovation. The paper pioneersthe cooperation between hotel management group and local property owners in terms of building and operating theme hotel. In addition, it proposes the innovative business model called "Bed and Breakfast" in the ethnic minority areas.
\end{abstract}

\section{Bringing forward of the conception}

\section{The Silk-road Economic Belt}

On September 3, 2013, Chairman Xi Jinping brought forward that China and the Central Asia Countries jointly build the "Silk-road Economic Belt" (herein after referred to as the "Economic Belt") in the way of innovative cooperation during the lecture at Nazarbayev University in Kazakhstan. The "five-access principle" of "policy communication, road connection, unimpeded trade, currency circulation and understanding of people's needs” offers a clear direction for the implementation of the conception of Economic Belt.

\section{Meaning of theme hotel}

The theme hotel, a foreign word, which is called themed hotel or theme hotel in English, is namely the themed hotel, theme hotel for short. In foreign countries, the theme hotel, design hotel, lifestyle hotel and boutique hotels etc. are called the unique concept hotels. Our domestic scholars give definitions in different aspects for the so-called theme hotel. It can be discovered by integrating the research results that the theme hotel is a hotel which uses a material as its theme and is operated around the specific theme from the hotel construction, decoration, hardware, software, products, services and even its operation and management styles. Wei Xiaoan (2005) pointed out that a theme hotel shall takes culture as its theme, takes the hotel as its carrier and guests as the essence of experience ${ }^{[1]}$. The concept can be interpreted as that the key of a theme hotel is the guests' theme culture experience, so the theme culture and theme experience become the key factors of the theme hotel which are different from other types of hotels.

\section{Development situation of Theme Hotels in Xinjiang}

\section{Current development situation}

Although Xinjiang possesses abundant tourism culture resources, there are only a few theme hotels reflecting the regional and ethnic characteristics of Xinjiang; the several principal theme hotels are only located in Urumqi Municipality, the provincial capital, and they have low levels and small scales. Please see Table I for the overview of theme hotels within the region. 
Table 1. Overview of Theme Hotels in Xinjiang

\begin{tabular}{c|c|c|c|c}
\hline Name of Hotel & Stars & Location & Characteristics & $\begin{array}{c}\text { Quantity of } \\
\text { Rooms }\end{array}$ \\
\hline Tumaris Grand Hotel & Four-star & Urumchi & Ethnic and religion & 171 \\
\hline Yinglan Theme Hotel & Three-star & Urumchi & Urban fashion & 53 \\
\hline Urumchi Bayinhe Hotel & Four-star & Urumchi & Music & 80 \\
\hline $\begin{array}{c}\text { Yema International Business } \\
\text { Hotel }\end{array}$ & Four-star & Urumchi & Culture and art & 164 \\
\hline Royal International Hotel & Five-star & Urumchi & European style & 200 \\
\hline
\end{tabular}

\section{Major problems}

Single theme and lack of regional culture characteristics

It can be discovered from filed investigations that Xinjiang's theme hotels are all in Urumchi, the provincial capital and most of them are four-star hotels with a few rooms. As far as the hotel themes are concerned, there are many culture, art and urban fashion themes but only a few hotels with themes embodying the ethnic and regional cultures. Since the regional ethnic culture and regional features and other core competence factors haven't been reflected in their themes, they lose the entire industrial competitiveness of theme hotels.

Small scale and single business pattern

Xinjiang's existing theme hotels have small scales and are incomplete. The average number of rooms of the interviewed five theme hotels is only 134 rooms and there are large gaps between their software and hardware in the hotels and these in the inland hotels. As far as the operation and management mode is concerned, all the theme hotels in Xinjiang adopt the independent management mode. However, if a four-star or five-star hotel, such as Tumaris Hotel and Royal Hotel, lacks the management by a professional management team, it is hard for it to maintain its existence in the hotel market of fierce competition.

\section{Lack of theme experience}

According to Wei Xiaoan's opinions, the theme hotel needs to embody the consumers' experience. $\mathrm{Xu}$ Jing (2009) pointed out that the $21^{\text {st }}$ century is the era of experience economy. The experience economy is the extension and deepening of service economy and the theme hotel is the product of experience economy ${ }^{[2]}$. If the guests cannot obtain comprehensive mind and body experience and feeling by watching, listening, smelling and tasting, the theme hotel will certainly go to the operational road of homogenization like other hotels. Therefore, the experience design became an important index to measure whether the theme hotel is different from other hotels. According to investigations, we found that the experience of theme hotels in Xinjiang is generally poor. While interviewing the managers of the hotels listed in Table I, the writer found that only the gallery, ecological garden etc. within the Yema International Hotel provide the guests with the chances of experiences and the ethnic songs and dances at the banquet hall of Tumaris Hotel is designed with the links which can be participated by guests, but other hotels hardly have any experience service. Even though the above two hotels have experience designs, their experience services only stay superficial and haven't permeated into the guests' entire accommodation process; besides, the disguised paid experience makes the guests more unsatisfied.

\section{Development countermeasures for theme hotels in Xinjiang}

\section{Innovation of themes}

For the theme selection of a theme hotel, it is required to fully consider the local regionalism, the development level of local economy and the development level of tourism. Located in west china, connecting the west China and the Central Asia, Xinjiang is the confluence province with the confluence of China section with the overseas section. In the conception of the Silk-road Economic Belt, Xinjiang holds the synergistic strategic position of the east and west. To develop the theme hotel integrated with ethnic, religion, regional culture, Silk-road culture depending on the cultural 
advantages of the ethnic region avails cultivating the competitive hotel industry of Xinjiang, promoting the entire development of Xinjiang's tourism and the economic growth in Xinjiang area.

By using the research thought of Wang Wei (2007) for reference, this paper defines the capitals of the five autonomous prefectures of Xinjiang as the tourist node cities and tourist distributing centers of each prefecture. For such city positioning offers an objective basis for the theme definition of hotel. According to the terrain of Xinjiang as well as the characteristics of distribution of minorities, develop and build hotels with the local minority culture as the themes in the central cities of each prefecture and let the theme hotels play the role in propagandizing the local tourism culture in virtue of the city positioning of central cities and tourist distributing centers. See Table II for the specific scheme of countermeasures.

Table 2. Table for Types of Theme Hotels and Extraction of Theme Elements in Each Prefectures of Xinjiang

\begin{tabular}{|c|c|c|c|}
\hline Prefecture & Prefecture Capital & Type of Theme & Extraction of Key Words \\
\hline $\begin{array}{c}\text { Kazak Autonomous } \\
\text { Prefecture of Ili }\end{array}$ & Yining & Kazakhstan style & $\begin{array}{c}\text { Prairie culture, "place } \\
\text { with south-China-type } \\
\text { scenery” and Kazakhstan } \\
\text { wedding customs }\end{array}$ \\
\hline $\begin{array}{l}\text { Bortala Mongol } \\
\text { Autonomous Prefecture }\end{array}$ & Bole & Mongolia style & $\begin{array}{l}\text { Wild animal, wrestling } \\
\text { and horse racing }\end{array}$ \\
\hline $\begin{array}{c}\text { Hui Autonomous } \\
\text { Prefecture of Changji }\end{array}$ & Changji & $\begin{array}{l}\text { The Hui nationality's } \\
\text { style }\end{array}$ & $\begin{array}{c}\text { Heaven Lake of Tian } \\
\text { Shan, North Court } \\
\text { Supervision Office } \\
\text { Historical Site, Dinosaur } \\
\text { fossil site, Populus } \\
\text { Euphratica Forest and the } \\
\text { Hui People's snacks }\end{array}$ \\
\hline $\begin{array}{c}\text { Bayingolin Mongol } \\
\text { Autonomous Prefecture }\end{array}$ & Korla & Mongolia style & $\begin{array}{l}\text { Bosten Lake, Bayanbulak } \\
\text { Grassland, Swan Lake, } \\
\text { Ancient City of Loulan } \\
\text { Ruins and Kunes National } \\
\text { Forest Park } \\
\end{array}$ \\
\hline $\begin{array}{c}\text { Kizilsu Kirghiz } \\
\text { Autonomous Prefecture }\end{array}$ & Atux & $\begin{array}{l}\text { Kyrgyz style and } \\
\text { Uyghur style }\end{array}$ & $\begin{array}{c}\text { Mount Tianshan, Kunlun } \\
\text { Mountains, Pamirs, Tarim } \\
\text { Basin and Manas }\end{array}$ \\
\hline
\end{tabular}

The extraction of key words in Table II offers the specific thinking for the theme innovation to the theme hotels in Xinjiang. After integrating the key words according to the five autonomous prefectures' own features, finally form the themes of all prefectures, which are different in elements but complementary and uniform as a whole, to embody the regional characteristic and ethnic looks of the whole Xinjiang area.

\section{Innovation of business mode}

Entrust a hotel management group to manage the hotel

A hotel management group, especially an international hotel management group, has its absolute advantages in market development, brand building, investment building, operation, management, marketing, human resources and other aspects. It can yet be regarded as an innovation of operation mode to jointly create the international-brand theme hotels with the Silk-road characteristics by virtue of the operating and management advantages of a hotel management group and by combining the outstanding local owners' asset and contact advantages.

Some objective conditions are required to cooperatively create the local theme hotels by virtue of the advantages of an international hotel management group because the management group will consider the local economic development level, tourism development level, city positioning, population density, market need, owner's background, economic strength and other factors while choosing a cooperative project. Since the central node cities on the north, middle and south roads of the ancient Silk Road in Xinjiang basically have the above-mentioned conditions, it is, to some degree, feasible to rebuild or build theme hotels with their management entrusted to an international hotel management company in the cities listed in Table II above. While choosing a management company, the local enterprise owners shall firstly consider the company with a high operating and 
management level and good performance and meanwhile shall also consider the management company's experience in creating and operating theme hotels.

Select owners with the sense of social responsibility

An important standard for an international hotel management group to search for a global partner is to select a proper owner. At present, the owners of the domestic high-star hotels are basically the foreign-funded enterprise, joint venture enterprise, state-owned enterprise and private enterprise. Due to the restriction of policies and other factors, there are relatively fewer foreign-funded enterprises and joint venture enterprises. Over recent years, the private real estate enterprises as hotel owners sprung up suddenly. While choosing a private enterprise for cooperation, the management group shall emphasize the owner's background and chose an enterprise with credit and sense of social responsibility as a cooperative partner, which makes for carrying out the management system and brand culture. During the development and operation of theme hotels, the enterprises with the sense of social responsibility can help to popularize the development of local tourism culture industry in Xinjiang.

\section{Actively develop the theme accommodation}

"Accommodation" came from Japanese "Minshuku". The traditional accommodation refers to the pattern that the countryside house owners provide the tourists with the guest rooms for accommodation and has many similarities with the British and American "Bed \& Breakfast" (B\&B for short). B\&B generally refers to a hotel or inn, which provides the guests with beds and breakfast, and amounts to our domestic family inn. The domestic popular "rural farmhouse" which offers accommodation is the closest to the initial definition of accommodation industry. Even thought there is the link of "visiting farmer's house" in the present tourism of Xinjiang, there is no authentic minority accommodation. There are a lot of minorities in Xinjiang and the minorities' life, customers and environments in north and south Xinjiang are apparently different. To actively develop the minority theme culture accommodation around the sceneries at the places where the minority people live can not only help to spread the minority culture and to solve the problem of employment of local people but also help create special products and services for Xinjiang tourism.

\section{Innovation of products and services}

Apart from the innovation of theme and of operation mode, the cores to make a theme hotel keep its sustainable competitiveness are products and services. To make efforts to dig out the elements of the ancient Silk Road in Xinjiang Section of the Economic Belt in virtue of the conception of Silk-road Economic Belt and by combining the product design technologies and service innovation concepts of modern hotel will naturally bring new profit growth points for the enterprises.

\section{Product innovation}

Firstly, the commodities in physical form in the hotel shall fully reflect the theme of the hotel. The high-star theme hotel can cooperate with a professional hotel product design company to design some tourist souvenirs which can not only reflect the ethnic culture characteristics of Xinjiang area but also manifest the hotel's brand logo, such as Xinjiang-characteristic dolls, bookmarks and fridge magnets with the pattern of ethnic regional style and other small gifts, which can be exhibited at the hotel's rooms and purchased by the guests. Besides, according to the hotel's theme, customize and purchase the non-material-benefit products, such as the dinnerware of the dining hall, room furniture, bedding articles and other articles to be used by the guests during their inhabitation; such non-material-benefit products shall serve the theme of hotel in their styles. Furthermore, all the equipment and facilities in the hotel, arrangement of the public area, soft decoration, lamplight, temperature, color etc. shall conform to the theme to build an atmosphere consistent with the theme from its hardware.

\section{Service innovation}

If a theme hotel wants to be different from an ordinary one, besides the difference in theme culture of hotel, to provide the personalized service, which is highly anastomotic with the theme of hotel, is exactly the coagulation point of competitiveness of hotel and also reflects the vitality of the theme hotel. However, the personalized service mentioned here is not only limited to the satisfactory service but also the innovative service with excellent quality, reasonable price and unexpectedly good feeling, namely, the "Wow" service we talked about usually. It shall reflect more theme experiences brought 
to the guests during the service. Take Xinjiang's theme hotels for example. For example, the room attendants can leave a note paper with a sentence in Uyghur for the guests while they stay in the hotel so that they may feel the minority's humanistic concern. For instance, the local specialty restaurant of Xinjiang can introduce the theme box and theme dishes in Chinese, English and Uyghur before the guests order; this can not only popularize the tourism culture and knowledge for the guests but also show the warm and hospitable Xinjiang service industry employees' high level and high quality. For the experience service, create a little theatre within the hotel by combining the catering service and let the local high culture and art go into the hotel so that the guests are able to learn the whole Xinjiang without leaving the hotel.

\section{Conclusion}

This paper puts forward the countermeasures such as innovation of theme, innovation of operation and management mode, product and service innovation for the development of Xinjiang's theme hotels through investigations and researches on the existing theme hotels in Xinjiang and by combining the conception of Silk-road Economic Belt so as to offer a new horizon and new thinking for the new development of hotel industry in Xinjiang. For the future research direction for this problem, it is also feasible to research it by combining the tourism enterprises, hotel industry, government, media and other stakeholders. Each innovative countermeasure can be deeply carried out as a empirical research project and this is to be jointly achieved by more scholars and industrial employees.

\section{References}

[1] Wei Xiaoan and Zhao Zhun. Theme Hotel, Guangdong Travel \& Tourism Press, 2005

[2] Xu Jing. Thought on Design Problems and Countermeasures of Ethnic Culture Theme Hotels Take the First Prairie Culture Theme Hotel of China as Example. Leading Edge, 2009,11

[3] Wang Wei. Research on Construction of Urban System of Tourism Center in China Section of the Silk Road. Journal Ningxia University (Natural Science Edition), 2007,28(4)

[4] Lu Zhihai, Deng Fengzhu. Research on Design Concept and Content of Regional Culture Theme Hotel. Journal of Guangdong AIB Polytechnic College, 2011,27 (1)

[5] Jing Xi. Cultural Positioning and Construction Supports for the Theme Hotel in the Ethnic Regions - Take Ningxia Hui Autonomous Region for Example. Social Scientists, 2012,7

[6] Kang Fen. Discussion on the Establishment and Management of Theme Hotels in Our Country Take Crown Plaza Hotel \& Resort Shenzhen for Example. Market Modernization, 2010,625 